\title{
Przygotowanie do małżeństwa oraz towarzyszenie młodym małżonkom poprzez budzenie wiary potrzebą chwili. Na kanwie przemówienia Franciszka do Roty Rzymskiej z 21 stycznia 2017 roku
}

Truizmem wydaje się stwierdzenie, iż zawarcie małżeństwa kanonicznego wymaga odpowiedniego przygotowania. Chodzi wszak o sprawę zupełnie zrozumiałą, zważywszy, iż wspólnota całego życia mężczyzny i kobiety, ze swojej natury skierowana ku dobru małżonków oraz ku zrodzeniu i wychowaniu potomstwa, podniesiona przez Chrystusa między ochrzczonymi do godności sakramentu, jest wyłączna i nierozerwalna ${ }^{1}$. W szczególności ten drugi istotny przymiot małżeństwa wymaga od nupturientów podjęcia głębszej refleksji, nie wspominając o potrzebie uświadomienia sobie przez nich samej istoty zawieranego związku.

Nic też dziwnego, że Ustawodawca kościelny zobowiązuje duszpasterzy do troski o to, by własna wspólnota kościelna świadczyła wiernym pomoc w tym, by stan małżeński był zachowany w duchu chrześcijańskim i by postępował w doskonałości (kan. 1063 in principio KPK). Pomoc ta powinna znaleźć swój wyraz w przepowiadaniu, katechezie dostosowanej do dorastających, młodzieży i dorosłych, z wykorzystaniem środków społecznego przekazu, tak by wierni byli pouczani o znaczeniu małżeństwa chrześcijańskiego oraz o zadaniach małżonków i rodziców chrześcijańskich (kan. 1063, n. 1 KPK), a także w osobistym przygotowaniu do zawarcia małżeństwa, poprzez które

1 Por. kan. $1055 \$ 1$ i 1056 KPK. 
to przygotowanie narzeczeni powinni być dysponowani do świętości swojego nowego stanu i obowiązków (kan. 1063, n. 2 KPK). Pomoc wspólnoty kościelnej winna poza tym objąć samych małżonków, tak by wiernie zachowując i broniąc przymierza małżeńskiego, dążyli do prowadzenia w rodzinie życia coraz bardziej świętego i pełnego (kan. 1063, n. 4 KPK).

W dobie sekularyzacji, w której coraz częściej odrzuca się wiarę, deprecjonuje się instytucję małżeńską i hołduje się mentalności prorozwodowej, przygotowanie do zawarcia małżeństwa wydaje się potrzebą chwili. Dał temu wyraz m.in. papież Franciszek w przemówieniu do Roty Rzymskiej z 21 stycznia 2017 roku². Wygłosił je w Sali Klementyńskiej Pałacu Apostolskiego podczas uroczystej inauguracji nowego roku sądowego, przyjmując na audiencji sędziów i pozostałych pracowników wymienionego Trybunału Apostolskiego oraz jego współpracowników. Było to już czwarte tego rodzaju spotkanie Franciszka z tymi, którzy wykonują na co dzień doniosłe zadanie w obszarze kościelnego wymiaru sprawiedliwości na tak wysokim szczeblu.

\section{Budzenie i ożywiane wiary znaczącym czynnikiem w przygotowaniu do małżeństwa}

Po pozdrowieniu wszystkich zgromadzonych, przede wszystkim audytorów rotalnych $\mathrm{z}$ dziekanem i mianowanym niedawno wicedziekanem Roty na czele, oraz po wyrażeniu życzenia kontynuowania przez Trybunał pracy w spokoju i z żarliwą miłością do Kościoła, papież Franciszek, jak sam zaznaczył, wrócił do poruszonego już wcześniej tematu relacji zachodzącej między wiarą i małżeństwem³ dotyczącego w szczególności perspektyw wiary ujętych w kontekście ludzkim i kulturowym, w którym kształtuje się intencja małżeńska.

\footnotetext{
2 Por. Francesco, Discorso alla Rota Romana (21.01.2017), http://w2.vatican.va/ content/francesco/oit/speeches/2017/januarii/21 (Dostęp: 05.02.2017).

3 Por. Francesco, Discorso alla Rota Romana (22.01.2016), ,L'Osservatore Romanao" z 23.01.2016, s. 8.
} 
Papież Jan Paweł II, zauważa jego następca, dobrze naświetlił opierając się na nauczaniu Pisma Świętego - ,jak głęboka jest więź między poznaniem wiary i poznaniem rozumowym [...]. Cechą wyróżniającą tekst biblijny jest przeświadczenie, że istnieje głęboka i nierozerwalna jedność między poznaniem rozumowym i poznaniem wiary" ". Dlatego też, gdy się bardziej oddala od perspektywy wiary, tym bardziej „człowiek naraża się na niepowodzenie i może ostatecznie znaleźć się w sytuacji «głupca». Według Biblii tego rodzaju głupota niesie ze sobą zagrożenie dla życia. Głupiec bowiem łudzi się, że posiada rozległą wiedzę, ale w rzeczywistości nie potrafi skupić uwagi na rzeczach istotnych. Nie pozwala mu to zaprowadzić ładu we własnym umyśle” (por. Prz 1, 7) ani przyjąć właściwej postawy wobec samego siebie i najbliższego otoczenia. Gdy wreszcie posuwa się do stwierdzenia, że «Boga nie ma» (por. Ps 14 [13], 1), ujawnia z całkowitą jasnością, jak znikoma jest jego wiedza i jak daleko mu jeszcze do pełnej prawdy o rzeczach, o ich pochodzeniu i przeznaczeniu" 5 .

Ze swej strony, kontynuuje Franciszek, papież Benedykt XVI w swoim ostatnim przemówieniu do Roty Rzymskiej (26 stycznia 2013 roku) przypomniał, że „jedynie przy otwarciu się na Boga [...] możliwe jest zrozumienie i realizowanie - w konkretnych warunkach życia małżeńskiego i rodzinnego - prawdy o człowieku jako Jego synu, odrodzonym we chrzcie [...]. Odrzucenie propozycji Bożej prowadzi w rezultacie do głębokiej nierównowagi we wszystkich relacjach ludzkich [...], łącznie z małżeńską" ${ }^{6}$. Niezwykle konieczne jest pogłębienie relacji między miłością i prawdą [podkr. w tekście - W. G.]. „Miłość, podkreśla Mówca nawiązując do swojej encykliki Lumen fidei, potrzebuje prawdy. Jedynie gdy jest oparta na prawdzie, miłość może

\footnotetext{
4 Jan PAweŁ II, Encyklika „Fides et ratio” Ojca świętego Jana Pawła II do biskupów Kościoła katolickiego o relacjach między wiarq a rozumem, Watykan 2016, s. 28-29, n. 16.

5 Por. Tamże, s. 32, n. 17.

6 Benedetto XVI, Discorso alla Rota Romana (26.01.2013), AAS 105 (2013), s. 168, n. 2 .
} 
trwać w czasie, pokonać krótkotrwały epizod i pozostać stałą dla podtrzymania we wspólnej drodze. Jeśli miłość nie ma odniesienia do prawdy, jest poddana zmianie uczuć i nie wytrzymuje próby czasu. Natomiast prawdziwa miłość łączy wszystkie elementy naszej osoby i staje się nowym światłem w kierunku życia wielkiego i pełnego. Bez prawdy miłość nie może ofiarować węzła trwałego, nie jest w stanie przenieść swojego «ja» ponad własną izolację, ani uwolnić tegoż «ja» od chwili przemijającej, by budować życie i przynosić owoc"7.

Nie możemy ukrywać, że upowszechniona mentalność, stwierdza Ojciec święty, zmierza do zaciemnienia dostępu do prawd odwiecznych. To mentalność, która wciąga, często w sposób szeroki i subtelny, stanowiska i postawy samych chrześcijan ${ }^{8}$, których wiara zostaje osłabiona i traci własną oryginalność kryterium interpretacyjnego i skutecznego dla istnienia osobowego, rodzinnego i społecznego. Taki kontekst, pozbawiony wartości religijnych i wiary, nie może nie warunkować również zgody małżeńskiej. Doświadczenia wiary tych, którzy pragną małżeństwa chrześcijańskiego są bardzo różne. Jedni uczestniczą aktywnie w życiu parafii, inni zbliżają się tu po raz pierwszy, inni znów prowadzą życie modlitwy nawet intensywnej; są zaś i tacy, którzy kierują się bardziej ogólnym sentymentem religijnym, nie brak i takich osób, którzy są daleko od wiary lub takich, którym wiary brak.

Wobec takiej sytuacji, konstatuje Papież, należy znaleźć skuteczne środki. Jako pierwszy środek wskazuje formację młodzieży realizowaną poprzez przygotowanie skierowane ku odkryciu małżeństwa i rodziny według zamysłu Boga. Chodzi tu o wspieranie przyszłych małżonków do przyjęcia łaski i „zasmakowania” w niej, a także do przyjęcia piękna i radości prawdziwej miłości, zachowanej i odkupionej przez Jezusa. Wspólnota chrześcijańska, do której zwracają się mający zawrzeć małżeństwo, jest wezwana do głoszenia tym osobom

\footnotetext{
7 Franciscus, Litterae encyclicae „Lumen fidei” (29.06.2013), AAS 105 (2013), s. 565 , n. 27.

8 Por. Franciscus, Adhortatio apostolica „Evangelii gaudium” (24.11.2013), AAS 105 (2013), s. 1050, n. 64.
} 
w sposób serdeczny Ewangelii, by ich doświadczenie miłości mogło stać się sakramentem, skutecznym znakiem zbawienia. W tej okoliczności misja odkupieńcza Jezusa dosięga mężczyznę i kobietę w konkretnej sytuacji ich życia i miłości. Moment ten staje się dla całej wspólnoty nadzwyczajną okazją do misji. Dzisiaj, bardziej niż kiedykolwiek, przygotowanie to jawi się jako prawdziwa i własna okazja ewangelizowania dorosłych, często tzw. oddalonych. Nie brak bowiem wielu młodych, dla których bliskość ślubu stanowi okazję do ,spotkania” na nowo wiary od dawna „odesłanej na margines ich życia”. Znajdują się oni zresztą w momencie szczególnym, charakteryzującym się często również ich dyspozycyjnością do rewizji i zmiany kierunku egzystencji. Może więc być to czas sprzyjający do odnowienia własnego spotkania z osobą Jezusa Chrystusa, z orędziem Ewangelii i z nauką Kościoła.

Należy jednak, kontynuuje Franciszek, by organizatorzy i organizmy powołane do duszpasterstwa rodzinnego byli ożywieni silną troską o to, by zawsze czynić bardziej skutecznymi drogi przygotowania do sakramentu małżeństwa, dla wzrostu nie tylko ludzkiego, lecz przede wszystkim wiary narzeczonych. Celem podstawowym spotkań jest wspieranie tych ostatnich w urzeczywistnianiu stopniowego włączania się w misterium Chrystusa, a także w Kościół, i z Kościołem. Niesie to ze sobą progresywne dojrzewanie w wierze, poprzez głoszenie Słowa Bożego, a także przystąpienie do Chrystusa i szlachetne postępowanie za Nim. Cel więc tego przygotowania polega na wspieraniu narzeczonych w poznaniu i przeżywaniu rzeczywistości małżeństwa, które zamierzają zawrzeć, tak by mogli uczynić je nie tylko ważnym i godziwym, lecz również owocnym, i by byli dysponowani uczynić tę celebrację etapem na ich drodze wiary. Do zrealizowania tego potrzebne są osoby ze specjalną kompetencją i właściwie przygotowane do takiej posługi, w odpowiedniej współpracy między kapłanami i parami narzeczonych.

Następnie papież Franciszek wyznaje, iż w takim właśnie duchu czuje potrzebę rozważenia konieczności „nowego katechumenatu” w przygotowaniu do małżeństwa. Mając na uwadze sugestie ojców 
ostatniego Zwyczajnego Zgromadzenia Synodu Biskupów" za coś pilnego uznaje konkretne urzeczywistnienie tego, co już zostało przedłożone w n. 66 adhortacji apostolskiej Familiaris consortio Jana Pawła $\mathrm{II}^{10}$, który zauważa, że tak jak dla przygotowania dorosłych

9 W „Relacji końcowej” XIV Zgromadzenia Ogólnego Synodu Biskupów zwrócono uwagę na potrzebę prowadzenia „kursów formacyjnych, które wspierałyby zarówno osobę, jak i parę w taki sposób, aby przekaz treści wiary był połączony z doświadczeniem życia dawanym przez całą wspólnotę kościelną. Skuteczność tej pomocy wymaga również, aby została udoskonalona katecheza przedmałżeńska niekiedy uboga w treści - która stanowi integralną część duszpasterstwa zwyczajnego [...]. Należy dokładnie uwzględniać trzy etapy wskazane przez Familiaris consortio (por. n. 66): przygotowanie dalsze, dokonujące się przez przekazywanie wiary i wartości chrześcijańskich we własnej rodzinie; przygotowanie bliższe, które zbiega się z programami katechezy i doświadczeniami formacyjnymi przeżywanymi we wspólnocie kościelnej; przygotowanie bezpośrednie do małżeństwa, stanowiące część szerszego procesu, któremu kierunek nadaje powołanie [do małżeństwa]”. Podkreślono również konieczność przeciwdziałania - w formacji przedmałżeńskiej - lansowaniu wzorców sprzecznych z chrześcijańską, a nawet ludzką wizją rodziny, m.in. poprzez tworzenie autentycznych i właściwych „duszpasterskich programów wsparcia”, skierowanych „zarówno do poszczególnych osób, jak i par, ze szczególnym uwzględnieniem wieku dojrzewania i dorastania, w którym trzeba pomóc odkryć piękno seksualności w miłości”. Zasygnalizowano ponadto potrzebę „poszerzenia tematów formacyjnych na kursach przedmałżeńskich, tak aby stały się one drogą wychowania do wiary i miłości, włączoną w proces wtajemniczenia chrześcijańskiego”. Postulowano wreszcie, by „kursy przygotowania do małżeństwa prowadziły także pary małżeńskie, aby mogły towarzyszyć narzeczonym przed ślubem oraz w pierwszych latach życia małżeńskiego". Synod BIsKupów. XIV Zwyczajne Zgromadzenie Ogólne, Relacja końcowa Synodu Biskupów dla Ojca świętego Franciszka (24 października 2015), w: Powołanie i misja rodziny w Kościele i świecie współczesnym. Dokumenty i komentarz. XIV Zgromadzenie Zwyczajne Synodu Biskupów, Kraków 2016, s. 83-85, nn. 57-58.

10 „Na tej bazie [przygotowania dalszego - W. G.] następnie oprze się mające znacznie szerszy zakres, przygotowanie bliższe [podkr. w tekście - W. G.], które począwszy od stosownego wieku i przy właściwej katechezie, jakby katechumenacie [podkr. - W. G.] - stanowi bardziej specyficzne przygotowanie do sakramentów, niejako do ponownego ich odkrycia”. W odniesieniu zaś do przygotowania bezpośredniego Jan Paweł II stwierdza, że ,zakres treści tego, co na tej, analogicznej do katechumenatu [podkr. - W. G.], drodze wiary należy przekazać, winno wejść także pogłębione poznanie tajemnicy Chrystusa i Kościoła, znaczenia łaski 
do chrztu katechumenat jest częścią procesu sakramentalnego, tak również przygotowanie do małżeństwa powinno stać się częścią integralną całej procedury sakramentalnej małżeństwa, jako antidotum, które zapobiega mnożeniu się zawierania małżeństw nieważnych czy nietrwałych ${ }^{11}$.

\section{Wspieranie młodych małżonków na drodze wiary}

Budzenie i pogłębianie wiary ma fundamentalne znaczenie nie tylko w procesie przygotowaniu do małżeństwa, lecz także w stosunku do tych, którzy małżeństwo już zawarli. Zdaniem Franciszka, wspieranie młodych małżonków na drodze wiary jest drugim środkiem zaradczym w zapobieganiu zawierania małżeństw nieważnych czy nietrwałych ${ }^{12}$. Za coś koniecznego uznaje on podjęcie, $\mathrm{z}$ odwagą i kreatywnością, projektu formacji młodych małżonków, z inicjatywą skierowaną ku wzrastaniu świadomości przyjętego sakramentu. Chodzi o dodawanie im odwagi w podejmowaniu refleksji nad różnymi aspektami ich codziennego życia, które jest znakiem i narzędziem miłości Boga wcielonego w historię ludzi.

Ojciec święty posługuje się tutaj dwoma wymownymi przykładami. Przede wszystkim, zauważa że miłość, którą nowa rodzina żyje,

i odpowiedzialności chrześcijańskiego małżeństwa, jak również przygotowanie do podjęcia czynnego i świadomego udziału w liturgicznym obrzędzie zaślubin”. JAN PAWEŁ II, Adhortacja apostolska „Familiaris consortio” Ojca świętego Jana Pawła II do biskupów, kapłanów i wiernych całego Kościoła katolickiego o zadaniach rodziny chrześcijańskiej wświecie współczesnym, Częstochowa 1982, s. 118-120, n. 66. 11 „In questo spirito, mi sento di ribadire la necessità di un «nuovo catecumenato» in preparazione al matrimonio. Accogliendo gli auspici dei Padri dell'ultimo Sinodo Ordinario, è urgente attuare concretamente quanto già proposto in Familiaris consortio (n. 66), che cioè, come per il battesimo degli adulti il catecumenato è parte del processo sacramentale, così anche la preparazione al matrimonio diventi parte integrante di tutta la procedura sacramentale del matrimonio, come antidoto che impedisca il moltiplicarsi di celebrazioni matrimoniali nulle o inconsistenti". Francesco, Discorso alla Rota Romana (21.01.2017)..., dz. cyt., s. 2-3.

12 „Un secondo rimedio di aiutare i nevelli sposi a prosequire il cammino nella fede e nella Chiesa anche dopo la celebrazione del matrimonio". TAмżE, s. 3. 
ma swoje korzenie i ostateczne źródło w Tajemnicy Trójcy Świętej, dzięki czemu rodzina niesie ów znak mimo trudu i niedostatków, z którymi musi się mierzyć we własnym życiu codziennym. Jako drugi przykład wskazuje, iż historia miłości chrześcijańskiej pary małżeńskiej stanowi część historii świętej, ponieważ jest zamieszkiwana przez Boga i ponieważ Bóg nigdy nie odstępuje od zobowiązania, które podjął z małżonkami w dniu ślubu; On bowiem jest „Bogiem wiernym i nie może zaprzeć się samego siebie” (2 Tm 2,13).

Wspólnota chrześcijańska, kontynuuje Papież, jest wezwana do przyjęcia, towarzyszenia i wspierania młodych par oferując okazje i odpowiednie narzędzia, poczynając od uczestniczenia we Mszy św. niedzielnej, do troski o życie duchowe tak wewnątrz życia rodzinnego, jak i w zakresie programu duszpasterskiego w parafii albo w stowarzyszeniach. Często młodzi małżonkowie są pozostawieni samym sobie, choćby wskutek zwykłego faktu, że nie widać ich w parafii; zdarza się to przede wszystkim wraz z narodzinami dzieci. Lecz właśnie w tych pierwszych momentach życia rodzinnego należy zagwarantować większą bliskość i mocne wsparcie, również w dziele wychowawczym dzieci, w stosunku do których są pierwszymi świadkami daru wiary.

Na drodze wzrastania ludzkiego i duchowego młodych oblubieńców pożądane jest, stwierdza Mówca, by istniały odpowiednie grupy, w których można by podejmować drogę formacji stałej: poprzez słuchanie Słowa Bożego, poruszanie tematów, które dotyczą życia rodzinnego, modlitwy i braterskiego dzielenia się ${ }^{13}$.

\section{Konkluzja przemówienia papieskiego}

Kończąc swoją alokucję, Franciszek stwierdza, że wskazane przez niego owe dwa remedia mają ukazać stosowny kontekst wiary w zawieraniu i przeżywaniu małżeństwa. Tak znaczący aspekt dla trwałości i prawdy sakramentu małżeńskiego wymaga od proboszczów, by byli zawsze bardziej świadomi delikatnego zadania, które jest im powierzone w trosce o małżeńską drogę sakramentalną przyszłych

13 TAMŻE. 
małżonków, i by czynili bardziej zrozumiałe i realne powiązanie między przymierzem i wiara [podkr. w tekście W. G.]. Chodzi o przejście od wizji czysto prawnej formalnej przygotowania przyszłych małżonków do rzeczywistości sakramentalnej od początku [podkr. w tekście - W. G.], to jest poczynając od drogi w kierunku pełni ich przymierza-zgody podniesionego przez Chrystusa do rangi sakramentu. Będzie to wymagać, dodaje Ojciec święty, szlachetnego wkładu chrześcijan dorosłych, mężczyzn i kobiet, którzy skupiają się u boku kapłana w duszpasterstwie rodzinnym dla budowania „arcydzieła społeczeństwa”, to jest „rodziny: mężczyzny i kobiety, którzy się kochają"14 według „rozświetlającego planu Boga”15.

Franciszek wyraża następnie życzenie, by Duch Święty, który zawsze kieruje we wszystkim Lud święty Boga, asystował i podtrzymywał wszystkich kapłanów i wiernych świeckich, którzy angażują się i będą się angażować na tym polu, aby nigdy nie utracili zapału i odwagi do zabiegania o piękno rodzin chrześcijańskich, mimo burzących zasadzek panującej kultury tego, co chwilowe i tymczasowe.

Papież Argentyńczyk przypomina wreszcie, iż wiele już razy mówił, iż trzeba dużej odwagi do zawarcia małżeństwa w czasach,

\footnotetext{
14 Por. FranciszeK, Katecheza $z 29$ kwietnia 2015, http:/Dmoch.net/jupgrade/ pliki/PDF/katechezy+srodowe+Franciszka+2025.pdf.

15 „La nostra riflessione avrà sempre presente la bellezza della famiglia e del matrimonio, la grandezza di questa realtà umana così semplice e insieme così ricca, fatta di gioie e speranze, di fatiche e sofferenze, come tutta la vita. Cercheremo di approfondire la teologia della famiglia e la pastorale che dobbiamo attuare nelle condizioni attuali. Facciamolo con profondità e senza cadere nella "casistica», perché farebbe inevitabilmente abbassare il livello del nostro lavoro. La famiglia oggi è disprezzata, è maltrattata, e quello che ci è chiesto è di riconoscere quanto è bello, vero e buono formare una famiglia, essere famiglia oggi; quanto è indispensabile questo per la vita del mondo, per il futuro dell'umanità. Ci viene chiesto di mettere in evidenza il luminoso piano di Dio sulla famiglia e aiutare i coniugi a viverlo con gioia nella loro esistenza, accompagnandoli in tante difficoltà, con una pastorale intelligente, coraggiosa e piena d'amore". Concistoro straordinario. Parole del papa Francesco (20.92.2014), https://w2.vatcican.va/content/francesco/it/speeches/2014/ febbraio/20/htm (dostęp 12.02.2017).
} 
w których żyjemy. A ci, którzy mają siłę i radość uczynienia tego ważnego kroku powinni czuć obok siebie czułość i konkretną bliskość Kościoła.

Życzenia dobrej pracy w nowym roku sądowniczym dla sędziów rotalnych i ich współpracowników, a także zapewnienie o modlitwie i prośba o nią oraz słowa papieskiego błogosławieństwa kończą alokucję ${ }^{16}$.

\section{Aktualność papieskiego wezwania}

Nietrudno zauważyć, że problematyce wiary - w relacji do małżeństwa - papież Franciszek poświęcił już drugą swoją alokucję wygłoszoną do Trybunału Apostolskiego Roty Rzymskiej. W pierwszej z nich, z 21 stycznia 2016 roku, dotknął wątku dotyczącego relacji wiary i małżeństwa w aspekcie ważności tego ostatniego. Ojciec święty stwierdzając, że wierni przystępujący do małżeństwa mają różny stopień wiary zaznaczył jednocześnie, że jakość wiary nie jest warunkiem istotnym zgody małżeńskiej, która, stosownie do stałej doktryny, może być zagrożona jedynie na płaszczyźnie naturalnej (por. kan. $1055 \$ 1-2 \mathrm{KPK}$ ). Habitus fidei bowiem zostaje wlany w momencie chrztu i kontynuuje swój tajemniczy wpływ na duszę, nawet gdy wiara nie została rozwinięta i psychologicznie wydaje się nieobecna. Brak uformowanej wiary, podobnie jak błąd co do jedności, nierozerwalności czy godności sakramentalnej małżeństwa niweczy konsens małżeński tylko wówczas, gdy determinuje wolę (kan. 1099 $\mathrm{KPK})^{17}$.

\footnotetext{
16 Francesco, Discorso alla Rota Romana (21.01.2017)..., dz. cyt., s. 3-4.

17 „E proprio perché è madre e maestra, la Chiesa sa che, tra i cristiani, alcuni hanno una fede forte, formata dalla carità, rafforzata dalla buona catechesi e nutrita dalla preghiera e dalla vita sacramentale, mentre altri hanno una fede debole, trascurata, non formata, poco educata, o dimenticata. È bene ribadire con chiarezza che la qualità della fede non è condizione essenziale del consenso matrimoniale, che, secondo la dottrina di sempre, può essere minato solo a livello naturale (cfr. $C I C$, can. $1055 \$ 1$ e 2). Infatti, l’habitus fidei è infuso nel momento del Battesimo e continua ad avere influsso misterioso nell'anima, anche quando la fede non è stata
} 
Tymczasem w przemówieniu z 21 stycznia 2017 roku Franciszek podejmuje wątek wiary $\mathrm{w}$ aspekcie przygotowania do małżeństwa oraz towarzyszenia młodym małżonkom. Opowiada się zdecydowanie za potrzebą budzenia i ożywiana wiary tak u jednych, jak i u drugich.

Gdy chodzi o złożony proces przygotowania do zawarcia małżeństwa, to Mówca zwraca uwagę na konieczność kształtowania u mających zawrzeć ten związek wiary jako rzeczywistości pozostającej $\mathrm{w}$ harmonii z rozumem. Odwołując się do encykliki Jana Pawła II Fides et ratio, zachęca narzeczonych do otwarcia się na Boga; odrzucenie Go burzy wszelkie relacje, także w życiu rodzinnym. Wzywa również do pogłębienia u pretendujących do zawarcia małżeństwa relacji między prawdą i miłością. Znaczące jest tutaj stwierdzenie, że brak wartości religijnych i wiary, nie może nie warunkować również zgody małżeńskiej. Oznacza to po prostu, że deficyt wiary może niejednokrotnie prowadzić do symulacji zgody małżeńskiej albo zdeterminowania woli przeciwnej jednemu z istotnych przymiotów małżeństwa lub jego charakterowi sakramentalnemu.

To, o czym mówi Franciszek, w pełni potwierdza doświadczenie duszpasterskie: przy okazji zawierania małżeństwa nietrudno stwierdzić u nupturientów znaczny deficyt operatywnej wiary, głębokie pokłady niewiedzy religijnej, traktowanie małżeństwa jako zwykłej umowy. Doświadczenie to jednak pozwala przyjąć i to, że w związku z zawieraniem małżeństwa wielu może zbliżyć się do wiary i do Chrystusa oraz „uzupełnic”” swoje dawne zaniedbania.

sviluppata e psicologicamente sembra essere assente. Non è raro che i nubendi, spinti al vero matrimonio dall'instinctus naturae, nel momento della celebrazione abbiano una coscienza limitata della pienezza del progetto di Dio, e solamente dopo, nella vita di famiglia, scoprano tutto ciò che Dio Creatore e Redentore ha stabilito per loro. Le mancanze della formazione nella fede e anche l'errore circa l'unità, l'indissolubilità e la dignità sacramentale del matrimonio viziano il consenso matrimoniale soltanto se determinano la volontà (cfr. CIC, can. 1099). Proprio per questo gli errori che riguardano la sacramentalità del matrimonio devono essere valutati molto attentamente". Francesco, Dicorso alla Rota Romana (22.01.2016), Communicationes 48 (2016), nr 1, s. 24. 
Rodzi się zatem generalny postulat, by w procesie przygotowania bezpośredniego do małżeństwa duszpasterze parafialni nie ograniczali się do rutynowego „spisywania” protokołu kanonicznego badania przedślubnego, lecz by - korzystając z okazji - umiejętnie skłaniali nupturientów zaniedbanych religijnie lub zagubionych w wierze do podjęcia głębszej refleksji nad własnym życiem w perspektywie tak znaczącego wydarzenia, jakim ma być zawiązanie przez nich rodziny. Apel taki wystosował do duszpasterzy m.in. Jan Paweł II w swoim przemówieniu do Roty Rzymskiej z 21 stycznia 1999 roku $^{18}$. Zwraca na to uwagę wielu przedstawicieli doktryny, którzy podkreślają, iż przede wszystkim od czasu Soboru Watykańskiego II należy okazywać większą troskę duszpasterską w procesie przygotowania do małżeństwa ${ }^{19}$. Franciszek, z właściwą sobie dynamiką idzie o krok dalej: pragnie, by troska ta zmierzała nie tylko do tego, by małżeństwa były zawierane

18 „Mi limito a sottolineare la grave responsabilità che incombe ai Pastori della Chiesa di Dio di curare una adeguata e seria preparazione dei nubendi al matrimonio: solo così, infatti, si possono suscitare nell'animo di coloro che si apprestano a celebrare le nozze le condizioni intelettuali, morali e spirituali, necessarie per realizzare la realtà naturale e sacramentale del matrimonio". GIOvANni PAOLO II, Discorso alla Rota Romana (21.01.1999), AAS 91 (1999), s. 627, n. 7.

19 Por. m. in. P. J. VIlAdRICH, Matrimonio y sistema matrimonial de la Iglesia, Ius Canonicum 54 (1987), s. 529; C. J. ERrázuriz, Il matrimonio e la famiglia quale bene giuridico ecclesiale. Introduzione al diritto matrimoniale canonico, Roma 2016, s. 104-110; L. GHisoni, La prevenzione della nullità del matrimonio nella preparazione immediata delle nozze, w: J. Kowal, M. Kovac (red.), Matrimonio e famiglia in una società multireligiosa e multiculturale. Giornata Accademica e Solenne Aatto Accademico della Pontificia Università Gregoriana 10 marzo 2011, Roma 2012, s. 53-77; T. PocaŁujko, La preparazione alle nozze e il diritto di contrarre un „matrimonio valido”, w: J. Kowal, M. Kovac (red.), Matrimonio e famiglia..., dz, cyt., s. 79-87; H. Fr ANCESCHI, Preparazione al. matrimonio e prevenzione della nullità, w: H. FranCESCHI, M.A. orTíz (red.), Verità del consenso e capacità di donazione. Temi di diritto matrimoniale e processuale canonico, Roma 2009, s. 63-102; W. GóRALSKI, Problem prewencyjnego zapobiegania nieważności małżeństw na drodze kanonicznego badania przedślubnego, Biuletyn [Stowarzyszenia Kanonistów Polskich] 26 (2016), nr 29, s. 43-69; S. TyкARski, Kryzys małżński jako wyzwanie dla duszpasterstwa. Studium teologiczno-pastoralne, Toruń 2015, s. 337-362. 
ważnie, lecz także by były owocne ${ }^{20}$; by dobrze uformowani, ugruntowani w wierze nupturienci otwierali się na Boga i Jego łaskę, i by rozumieli walor przyjmowanego sakramentu, który ma owocować w ich wspólnocie. Następca Benedykta XVI usilnie więc zabiega o to, by nikt spośród tych, który decydują się na przymierze małżeńskie, nie znalazł się w sytuacji biblijnego „głupca”.

Gdy w istniejących uwarunkowaniach kulturowych coraz częściej małżeństwo zawierają osoby mało religijne lub religijnie obojętne, gdy ich wiara pozostawia wiele do życzenia, a ignorancja w niektórych podstawowych sprawach (np. w odniesieniu do charakteru sakramentalnego małżeństwa czy jego nierozerwalności) jest wręcz żenująca, nie sposób nie podejmować stosownych działań duszpasterskich, które stanowiłyby antidotum na owe bolączki. Franciszek widzi tutaj konieczność prowadzenia - $\mathrm{w}$ ramach procesu przygotowania do małżeństwa - nowego katechumenatu, postulowanego już w Familiaris consortio. Miałby on służyć „pogłębionemu poznaniu tajemnicy Chrystusa i Kościoła, znaczenia łaski i odpowiedzialności chrześcijańskiego

${ }^{20}$ Gdy chodzi o wymóg wiary do zaistnienia małżeństwa „owocnego”, to trafne wydaje się następujące wyjaśnienie B. Ndubuezeza Ejena (Ammissione alle nozze. La „misericordia preventiva” della normativa e della pastorale prematrimoniali, w: C. J. errazuriz, M. A. ortíz (red.), Misericordia e diritto nel matrimonio. Giornata di studio, Roma 22 maggio 2014, Roma 2014, s. 56): „Na pytanie, czy wiara jest konieczna do dopuszczenia [kogoś - W. G.] do małżeństwa, należy odpowiedzieć pozytywnie, szybko precyzując, że konieczności tej nie należy rozumieć w sensie absolutnego obowiązku prawnego, lecz jako wymóg owocnego rezultatu małżeństwa, i uwzględniając uwagę, iż niedoskonała dyspozycja nadprzyrodzona nie ma znaczenia motywu do zakazu zawarcia małżeństwa nupturientom właściwie dysponowanym na płaszczyźnie właściwej intencji małżeńskiej, która, per se, jest otwarta na pomoc Bożą” („Alla domanda, quindi, se la fede sia necessaria per l'ammissione al matrimonio bisogna rispondere affermativamente, precisando subito tuttavia che detta necessità non si intende in senso di un obligo giuridico assoluto bensi come esigenza dell'esito fruttuoso del matrimonio e premettendo il caveat che l'imperfetta disposizione soprannaturale non vale come motivo per negare le nozze ai nubendi ben disposti [podkr. w tekście - W. G.] sul piano della retta intenzione matrimoniale che, di per sé, è già aperta all'aiuto divino"); por. także Benedetto XVI, Discorso alla Rota Romana (26.01.2013), AAS 105 (2013), s. 169, n. 2. 
małżeństwa”, jak również przygotowaniu „do podjęcia czynnego i świadomego udziału w liturgicznym obrzędzie zaślubin"21.

Katechumenat przedmałżeński, stanowiący istotny element zarówno bliższego, jak i bezpośredniego przygotowania do małżeństwa, powinien stanowić określony cykl katechez, których tematyka obejmowałaby nie tylko kwestie z zakresu teologii małżeństwa i rodziny, lecz także zagadnienia bardziej ogólne związane z podstawowymi prawdami wiary. Zgodnie z zamysłem papieża Franciszka chodziłoby bowiem o pogłębienie u przyszłych małżonków wiary. Wydaje się, że tzw. kursy przedmałżeńskie należałoby przekształcać właśnie w instytucję katechumenatu przedmałżeńskiego (z poszerzoną tematyką katechez). Tak zresztą dzieje się już w wielu diecezjach, m.in. w Polsce ${ }^{22}$. Jak słusznie zauważa C. J. Errázuriz, jakkolwiek owe kursy przedmałżeńskie są bardzo pożyteczne (jeśli wpływają na życie przyszłych małżonków), to jednak stanowią jedynie środek pomocniczy w stosunku do tego, co pozostaje zawsze głównym środkiem zwyczajnym i bardziej skutecznym. A jest nim żywotne uczenie się tego, co implikuje jak być mężem, żoną, rodzicem oraz nieodłącznie: co znaczy być nim (nią) w Panu, poprzez pozostawanie - jako syn lub córka w rodzinie chrześcijańskiej albo poprzez życie we wspólnocie chrześcijańskiej $^{23}$. W ten sposób kanonista z Santa Croce chce podkreślić walor przygotowania (dalszego) do małżeństwa we własnej rodzinie ${ }^{24}$.

21 Jan Pawe -120, n. 66.

22 Przyjęte przez Konferencję Episkopatu Polski (1 maja 2003 roku) Dyrektorium duszpasterstwa rodzin, Warszawa 2003, przewiduje prowadzenie w każdej parafii (niezależnie od katechizacji w szkole) - ,jako program optymalny - prowadzenie dla młodzieży rocznej katechizacji przedmałżeńskiej [podkr. w tekście - W. G.] obejmującej co najmniej 25 spotkań, analogicznie do przygotowania przed I Komunią św., czy przed bierzmowaniem” (s. 26, n. 25). Taką formę katechizacji (przewidzianą dla młodzieży szkół ponadgimnazjalnych) można uznać za rodzaj katechumenatu przedmałżeńskiego.

23 C. J. ERrÁzUriz, Il matrimonio e la famiglia quale bene giuridico ecclesiale..., dz. cyt., s. 104.

${ }^{24}$ „Pokora w stosunku do możliwości prawa, zauważa M. ANDRzEJEwski, każe stwierdzić, że w kwestii przygotowania do małżeństwa nic nie zastąpi przykładu 
Akcentowanie znaczenia wychowywania do przyszłego życia małżeńskiego w rodzinie, również w wymiarze kształtowania wiary, w pełni harmonizuje z tym, co papież Franciszek stwierdza w adhortacji apostolskiej Amoris laetitia: „Przekazywanie wiary dzieciom, w sensie ułatwiania jej wyrażania i rozwoju, pozwala, aby rodzina stawała się narzędziem ewangelizacji i zaczynała jej powierzanie wszystkim tym, którzy stają się jej bliscy, również poza samym środowiskiem rodzinnym" ${ }^{25}$. Warto w tym miejscu przytoczyć również następujący fragment wymienionego dokumentu papieskiego, który to fragment można odnieść do postulatu prowadzenia katechumenatu przedmałżeńskiego: „Istnieje konieczność większego zaangażowania całej wspólnoty, z pokreśleniem szczególnego znaczenia świadectwa samych rodzin, a także zakorzenienia przygotowania do małżeństwa w procesie inicjacji chrześcijańskiej z chrztem oraz innymi sakramentami" ${ }^{26}$.

Przyjęta przez Ojca świętego diagnoza dotycząca upowszechniającej się mentalności pozbawionej odniesienia do dóbr nadprzyrodzonych skłania go do zwrócenia bacznej uwagi również na konieczność formowania tych, którzy zawarli już małżeństwo. Przede wszystkim chodzi o małżonków, którzy przeżywają pierwszą, bardzo ważną fazę nowo zawiązanej wspólnoty życia.

Już w adhortacji apostolskiej Familiaris consortio usilnie zachęca się lokalne wspólnoty kościelne do „okazywania pomocy parze małżeńskiej w odkrywaniu i przeżywaniu przez nią nowego powołania i posłannictwa [...]”, co „odnosi się przede wszystkim do młodych rodzin, które w kontekście nowych wartości i nowej odpowiedzialności

rodziców wspieranego edukacyjną i formacyjną pracą szkół, kościołów oraz związków wyznaniowych" (Ochrona prawa do zawarcia małżeństwa i założenia rodziny w prawie polskim (wybrane problemy), w: W. GóRALSKI (red.), Ius connubii - ochrona i ograniczenia w prawie międzynarodowym, polskim i kanonicznym, Płock 2016, s. 54. 25 Francesco, „Amoris laetitia”. Esortazione apostolica sull'amore nella familia, Città del Vaticano-Cinisello Balsamo 2016; Tekst polski: OjCıEc święTy FrANCIszek, Posynodalna Adhortacja Apostolska „Amoris laetitia” o miłości w rodzinie (19.03.2016), Kraków 2016, s. 228, n. 289.

26 TAмżE, s. 162, n. 206. 
są bardziej niż inne wystawione, zwłaszcza w pierwszych latach po ślubie, na ewentualne trudności, tak te, które są związane z dostosowaniem się do wspólnego życia czy z przyjściem na świat dzieci”27. W omawianym przemówieniu do Roty Rzymskiej papieżowi Franciszkowi chodzi właśnie o wspieranie młodych par małżeńskich przez wspólnoty chrześcijańskie; $z$ natury rzeczy będą to przede wszystkim wspólnoty parafialne.

O potrzebie niesienia pomocy, także na drodze wiary, małżonkom przeżywającym swoje pierwsze lata życia małżeńskiego, następca Benedykta XVI szerzej wypowiedział się w adhortacji apostolskiej Amoris laetitia. Znamienne jest tutaj stwierdzenie, iż „nowożeńcy muszą uzupełnić ten proces, który powinien się dokonać w okresie narzeczeństwa" ${ }^{28}$. Gdy chodzi o kształtowanie ich wiary, aktualne jest stwierdzenie, że otrzymane przez małżonków błogosławieństwo (w zawieraniu związku) ,jest łaską i impulsem na tej stale otwartej drodze”29, podobnie jak to, w myśl którego „im bardziej małżonkowie starają się słuchać w swoim sumieniu Boga i Jego przykazań (por. Rz 2,15) i poddają się towarzyszeniu duchowemu, tym bardziej ich decyzja będzie wewnętrznie wolna od subiektywnego osądu i od dostosowania się do sposobów zachowania się ich środowiska"30. Mówiąc zaś o towarzyszeniu duszpasterskim młodym parom małżeńskim Ojciec święty wypowiada znamienne zdanie: „My duszpasterze powinniśmy zachęcać rodziny do wzrastania w wierze"31.

Wracając do alokucji papieskiej wygłoszonej do Roty Rzymskiej 21 stycznia 2017 roku należy zauważyć, iż Ojciec święty generalnie zwraca uwagę na potrzebę wspierania młodych małżonków na drodze ich wiary przez wspólnoty parafialne oraz specjalne grupy umożliwiające tymże parom małżeńskim stałą formację duchową.

\footnotetext{
27 Jan PAweŁ II, Adhortacja apostolska „Familiaris consortio”..., dz. cyt., s. 126, n. 69.

28 Francesco, „Amoris laetitia”..., dz. cyt., s. 172, n. 217.

29 TAMŻE, s. 173, n. 218.

30 TAMŻE, s. 176, n. 222.

31 TAMżE, s. 180, n. 227.
} 


\section{Zakończenie}

Zaprezentowane, już czwarte przemówienie Franciszka do Trybunału Roty Rzymskiej stanowi niewątpliwie znaczący element Magisterium papieskiego w doniosłym obszarze życia i aktywności Kościoła, jakim jest małżeństwo i rodzina. Tym razem swoją troskę pasterską Ojciec święty skierował ku przygotowującym się do małżeństwa oraz młodym małżonkom. Uznając za ważne zadanie budzenia i ożywiania wiary u jednych i drugich, dał wyraz przekonaniu, iż relacja zachodząca między małżeństwem i wiarą, dwiema rzeczywistościami ściśle ze sobą powiązanymi, ma wymiar nie tylko jurydyczny, lecz również teologiczny.

\section{Preparation for marriage and accompanying young souses by awakening faith - the need of the hour. On the basis on the speech of Pope Francis to Roman Rota of 21 January 2017}

\section{Summary}

The speech (fourth so far) given on 21 of January 2017 by Pope Francis to the Tribunal of the Roman Rota constitutes an important element of papal Magisterium in the important area of the life and activity of the Church, namely marriage and family. This time, the Holy Father focused on those preparing for marriage and young spouses. Considering the task of awaking and reviving faith both in the former and the latter, he expressed a view that the relationship between marriage and faith, two closely related realities, not only involves the juridical, but also theological dimension. Therefore, a concluded marriage should be both important, but also fruitful.

In the Pope's opinion, Christian communities, above all parish ones, play an especially important role in awakening and reviving faith in bridegrooms-to-be and young spouses. 